УДК 332.3

Шворак Анатолій, доктор економічних наук, доцент,

Волинський національний університет імені Лесі Українки, кафедра аналітичної економіки та природокористування м Луцьк; ORCID ID: 0000-0003-2077-5308 e-mail: ams95@ukr.net

https://doi.org/10.29038/2786-4618-2021-01-52-57

\title{
ЗБАЛАНСОВАНИЙ СОЩАЛЬНО-ЕКОНОМІЧНИЙ РОЗВИТОК СІЛЬСЬКИХ ТЕРИТОРІЙ - ОСНОВНЕ ЗАВДАННЯ ЗЕМЕЛЬНОЇ РЕФОРМИ
}

Анотація. У статті висвітлено проблеми розвитку сільських територій України. Встановлено, що дія нових соціально-економічних та геополітичних факторів спричинила появу цілої низки проблем, серед яких необхідно зазначити: скорочення кількості малих сільських населених пунктів, фермерських господарств та особистих селянських господарств, недостатній розвиток інфраструктури сільської місцевості.

Ключові слова: сільські території, земельна реформа, сільськогосподарські вгіддя, охорона земель, фермерські господарства, зайнятість населення.

Шворак Анатолий, доктор экономических наук, доцент, Волынский национальный университет имени Леси Украинки, кафедра аналитической экономики и природопользования, г. Луцк

\section{СБАЛАНСИРОВАННОЕ СОЦИАЛЬНО-ЭКОНОМИЧЕСКОЕ РАЗВИТИЕ СЕЛЬСКИХ ТЕРРИТОРИЙ - ОСНОВНАЯ ЗАДАЧА ЗЕМЕЛЬНОЙ РЕФОРМЫ}

Анотация. В статье проанализированы основные проблемы развития сельских территорий с учетом современных реалий. Сельские территории традиционно занимали особенное место в формировании демографического, экономического, ресурснопроизводственного и социальногуманитарного потенциала Украины. Нынешний этап социального развития сельских территорий в силу изменения способа сельскохозяйственного производства и внедрения промышленных технологий выращивания сельскохозяйственных культур и ухода за скотом характеризуется постепенным отмиранием “неперспективных" сельских поселений. Решение проблем развития сельских территорий должны включать следующие меры: формирование нормативно-правовой базы в сфере занятости сельского населения, создание мощной консультационной службы, профессионально-образовательную подготовку кадров, которая повысит качество рабочей силы, что позволит сберечь и создать новые рабочие места, будет способствовать развитию предпринимательства и самостоятельной занятости населения.

Ключевые слова: сельские территории, земельная реформа, сельскохозяйственные угодья, охрана земель, фермерские хозяйства, занятость населения.

Shvorak Anatoliy, Doctor of Economics, Professor, Lesya Ukrainka Volyn National University, Department of AnalyticaEconomics and Nature Management, Lutsk

\section{BALANCED SOCIAL AND ECONOMIC DEVELOPMENT OF RURAL TERRITORIES - MAIN TASK OF LAND REFORM}

Annotation. The article analyses the main problems of development of rural territories in the conditions of decentralization concerning modern realities. Rural territories traditionally took special place in the formation of demographic, economic, resource-production and social-humanitarian potential of Ukraine. The present stage of social development of rural territories concerning change of the method of agricultural production and introduction of industrial technologies of growing agricultural crops and cattle care is characterized by the gradual extinction of "nonperspective" rural settlements. The solving of rural territories development problems must include the following 
measures: the formation of regulatory framework in the sphere of rural population employment, the creating of powerful consulting service, professional-education training of personnel, which will increase the quality of workforce, that will allow to save and create the new working places, will promote the development of entrepreneurship and independent employment of population.

Key words: rural territories, land reform, agricultural grounds, land protection, farms, population employment

Постановка проблеми: У сучасних умовах реалізації довгострокових планів розвитку держави, євроінтеграційних прагнень України, а також досягнення цілей розвитку все більшої актуальності набуває проблема розвитку сільських територій та малого і середнього агробізнесу як основи майбутньої економічної безпеки.

Метою статті $\epsilon$ аналіз раціонального використання земельних ресурсів на основі яких формується збалансований соціально-економічний розвиток сільських територій. Нинішній етап розвитку сільського господарства України супроводжується загостренням низки соціальноекономічних проблем в зв'язку з впровадженням ринку землі. Стратегічно визначене і ресурсно підкріплене державне регулювання розвитку малого та середнього агробізнесу має забезпечити розвиток інфраструктури сільської місцевості, зростання продуктивності праці аграріїв, поліпшення соціального добробуту, збільшення надходжень до бюджетів громад. У результаті чого має зрости рівень життя населення.

Виклад основного матеріалу: Земельна реформа - це одна 3 ключових реформ країни, стратегічно важливий шлях економічного розвитку України, в результаті якої формується земельний устрій країни прийнятний для ефективної господарської діяльності на землі, створення організаційно-правових, економічних, наукових та інших соціальних засад для здійснення різних форм господарювання. Завдання земельної реформи - упорядкувати ринок землі, унеможливити корупційні схеми у земельних відносинах, зробити відносини у сфері землеустрою — зрозумілими й прозорими, і головне - дати поштовх українській економіці. Мораторій, котрий існував більше двадцяти років сформував тіньовій ринок землі, не створив ефективного господаря середнього класу - фермера, що призвело до низької продуктивністі фермерських госодарств, розкрадання землі через схеми, корупцію на ринку землі та зубожілі села. Офіційна статистика відображає цей процес не в повному масштабі: за даними Держстату, із 1990 по 2018 роки зникли з карти України 426 сільських населених пунктів. Однак справжня кількість «вимерлих» сіл набагато більша: 2014-го 369 безлюдних сіл просто не були зняті з державного обліку (Інститут демографії та соціальних досліджень НАНУ, 2017). На межі зникнення перебуває ще 4684 села, де станом на 2015 рік мешкало до 50 осіб у кожному. Селоутворюючими елементами для більшості поселень, крім приміських, $\epsilon$ сільгоспвиробництво, орна земля, пасовища, сади та ландшафтний потенціал території. За нинішнього стану наявності трудових ресурсів було б доцільно забезпечити норматив створення одного робочого місця на кожні 15-20 гектарів землекористування для сільгосппідприємств або напрацювати механізм сплати компенсацій для створення робочих місць у громадах та сільських, селищних радах за винятком фермерських господарств площею в межах 100 гектарів. Аналогічні нормативи діють у країнах Європи, особливо в регіонах Франції. Зберегти існуючу систему розселення непросто, але відновити і знову освоїти території дорожче в сотні разів. Раціональне використання природних, а особливо земельних ресурсів, вимагає збереження існуючих систем розселення та поселенської мережі.

В Україні виникнення агрохолдингів пов'язано з недосконалістю і провалами економіки, відсутністю необхідних інституційних і правових умов для ведення ефективного бізнесу, неадекватною політикою держави. Динаміка розвитку агрохолдингів та їх середня площа наведені в таблиці $1,2$.

Кількість агрохолдингів та фермерських господарств в Україні*

\begin{tabular}{|c|c|c|}
\hline Показник & 2007 & 2018 \\
\hline Кількість холдингів & 18 & 18 \\
\hline Загальна площа в користуванні, млн.. га & 1,8 & 3,568 \\
\hline Середня площа одного холдингу, тис.га & 100 & 198 \\
\hline
\end{tabular}

*3а даними Українського клубу аграрного бізнесу та сайту LATIFUNDIST. com. 
Аналізуючи дані наведені в таблиці 2 ми спостерігаємо, що йде значне зменшення кількості господарств площею до 100 гектарів та незначне збільшення за їх рахунок господарств площею від100-1000 гектарів, але кількість господарств в цих двох групах зменшилась за п’ять років на 6597, а площа земель яку вони обробляють на 89,6 тис. га. Особливо загрозливих наслідків зменшення спостерігається в групі до 100 га. Всі ці фермери проживають в тих населених пунктах де розміщена їх земля, і відповідно наповнюють бюджети місцевих рад, або територіальних громад. Відповідна картина склалася в господарствах які знаходяться в групі від 1000 - 5000 га кількість зменшилась на 496, площа на 1405,1 тис. га, відповідно в групі від $5000-7000$ га. зменшилась на 120 , площа на 766.1тис. га.

Табличя 2

Середній розподіл сільськогосподарських угідь за групами аграрних підприємств*

\begin{tabular}{|c|c|c|c|c|c|c|c|c|c|}
\hline \multirow{3}{*}{$\begin{array}{c}\text { Група підприємств за } \\
\text { розміром } \\
\text { землекористування, га }\end{array}$} & \multirow{2}{*}{\multicolumn{3}{|c|}{$\begin{array}{c}\text { Кількість } \\
\text { підприємств, од. }\end{array}$}} & \multicolumn{6}{|c|}{ Площа сільськогосподарських угідь } \\
\hline & & & & \multicolumn{3}{|c|}{ тис. га } & \multicolumn{3}{|c|}{$\begin{array}{c}\text { середня на одне } \\
\text { підприємство, га }\end{array}$} \\
\hline & 2005 & 2013 & 2018 & 2005 & 2013 & 2018 & 2005 & 2013 & 2018 \\
\hline До 5,0 & 6267 & 5018 & 2972 & 20,2 & 16,0 & 9,5 & 3,2 & 3,2 & 3,2 \\
\hline $5,1-10,0$ & 4303 & 3752 & 2594 & 34,1 & 29,5 & 19,5 & 7,9 & 7,9 & 7,8 \\
\hline $10,1-20,0$ & 5211 & 4790 & 3811 & 80,8 & 74,3 & 59,1 & 15,5 & 15,5 & 15,5 \\
\hline $20,1-50,0$ & 14830 & 13305 & 11076 & 564,8 & 504,3 & 417,3 & 38,1 & 37,9 & 37,7 \\
\hline $50,1-100,0$ & 4617 & 5283 & 4903 & 327,8 & 383,3 & 354,5 & 71,0 & 72,6 & 72,2 \\
\hline Всього до 100 & 31358 & 32148 & 25835 & 1027,7 & 993,0 & 859.9 & 32,8 & 27,1 & 33,2 \\
\hline $100,1-500,0$ & 7556 & 7253 & 7573 & 1849,0 & 1851,1 & 1797,1 & 244,7 & 244,9 & 243,8 \\
\hline $500,1-1000,0$ & 2986 & 2668 & 2704 & 2156,8 & 1910,4 & 1932,9 & 722,3 & 716,0 & 713,5 \\
\hline Всього віd 100-1000 & 10542 & 9921 & 10227 & 4005.8 & 3686.5 & 3730,0 & 380,0 & 371,6 & 364,7 \\
\hline $1000,1-2000,0$ & 3253 & 2534 & 2447 & 4651,4 & 3637,2 & 3513,0 & 1429,9 & 1435,4 & 1439,3 \\
\hline $2000,1-3000,0$ & 1482 & 1256 & 1063 & 3610,8 & 3053,3 & 2594,0 & 2436,4 & 2431,0 & 2443,9 \\
\hline $3000,1-4000,0$ & 755 & 614 & 467 & 2616,6 & 2128,0 & 1612,4 & 3465,7 & 3465,8 & 3472,2 \\
\hline $4000,1-5000,0$ & 362 & 319 & 250 & 1619,5 & 1415,8 & 1109,8 & 3911,0 & 4438,2 & 4478,6 \\
\hline Всього віd1000-5000 & 5852 & 4723 & 4227 & 12498,3 & 10234,3 & 8829,2 & 2135,7 & 2646,3 & 2088,8 \\
\hline $5000,1-7000,0$ & 300 & 339 & 258 & 1724,2 & 1964,2 & 1497,0 & 5747,3 & 5794,1 & 5874,9 \\
\hline $7000,1-10000,0$ & 103 & 166 & 127 & 847,1 & 1401,4 & 1057,5 & 8224,3 & 8442,2 & 8261,6 \\
\hline Всього від 5000-7000 & 403 & 505 & 385 & 2571,3 & 3320.6 & 2554,5 & 6380,4 & 6575,4 & 6635,1 \\
\hline Більше 10000,0 & 52 & 178 & 180 & 680,9 & 3466,2 & 3977,6 & 13094,2 & 19473,0 & 22209,8 \\
\hline
\end{tabular}

*Джерело: розроблено автором за даними Держкомстату

В групі підприємств та розміром сільськогосподарських угідь більше 10000 га ми спостерігаємо позитивну динаміку. В 2005 році було сконцентровано 680,9 тис. га сільськогосподарських земель, в 2013 році 3466,2 тис. га, а в 2018p. - 3977,6 га земель. Їх кількість становила відповідно 2005 р. - 52, 2013 - 178, 2018 p. - 180, а середня площа 2005 р. - 13094.2 га, 2013 р. - 19437,0 га, 2018 p. - 22209,8 га. Загальна площа земель, яку обробляли сільськогосподарські підприємства становить 20005,2 тис. га, а кількість найманих працівників становить 474,6 тисяч, включаючи галузь тваринництва та переробку сільськогосподарської продукції. На одного найманого працівника припадає 42,2 гектара земель.

Площа земель наданих для ведення особистого господарства в 2019 році становила 4945, тис. га, а їх кількість 3996,5 тис., в 2020році відповідно: 4946,2 тис. га та 3975,1.

Середній розмір особистих господарств становив в 2005 році - 1,08 га, 2019 році -1,2 Зга, а в 2020 році - 1,24 га. Згідно перепису сільське населення в1989 році становило 17,1 млн жителів, в 2014 році -14,2 млн жителів, 2015 році - 13,3 млн жителів, а 2019 році - 12,9 млн жителів.

Вплив агрохолдингів на ринок оренди землі є дуже великим. Загалом це в деякій мірі позитивний вплив, адже агрохолдинги, витісняючи фермерів з ринку оренди сільськогосподарської 
РОЗДІЛ І. Економіка. 1, 2021

землі, змушують їх змінювати свою спеціалізацію, переходити від вирощування низько ефективних зернових і технічних культур до вирощування овочів, фруктів, ягід.

Таблиия 3

\begin{tabular}{|l|l|l|l|l|l|}
\hline \multicolumn{1}{|c|}{ Показник } & \multicolumn{5}{c|}{ Роки } \\
\cline { 2 - 6 } & \multicolumn{1}{|c|}{2005} & 2016 & \multicolumn{1}{c|}{2017} & 2018 & \multicolumn{1}{c|}{2019} \\
\hline Кількість особистих селянських господарств, тис & 4915,3 & 4108,4 & 4035,2 & 4031,7 & 3996,5 \\
\hline Площа, тис.га & 6760,1 & 6307,2 & 6268,0 & 6175,6 & 6132,2 \\
\hline Землі для ОЖБ, тис.га & - & 809,1 & 799,7 & 793,3 & 731.0 \\
\hline Землі для ОСГ, тис.га & - & 2603,3 & 2580,9 & 2551.3 & 2513,4 \\
\hline Землі для товарного с/г виробництва,тис.га & - & 2837,1 & 2818,9 & 2799,3 & 2777,1 \\
\hline Втч на правах оренди,тис.га & - & 315,9 & 330,2 & 338,5 & 345,0 \\
\hline Наявність техніки, тис.шт & 178,9 & 207,0 & 218,0 & - & 232,0 \\
\hline Численність голів ВРХ, тис голів & 4022,3 & 2479,8 & 2468,4 & 2364.2 & 2194,8 \\
\hline
\end{tabular}

*Джерело: розроблено автором за даними Держкомстату

Посилення конкуренції на ринку оренди сільськогосподарської землі є позитивним чинником і призводить до підвищення рівня орендної плати за землю. В той же час, існування агрохолдингів можна розглядати як головну загрозу для економічної конкуренції у аграрній сфері.

Таблиия 4

Частка господарств населення у виробництві продукції сільського господарства, \% *

\begin{tabular}{|l|l|l|l|l|l|l|}
\hline \multicolumn{1}{|c|}{ Показник } & \multicolumn{1}{c|}{1990} & \multicolumn{1}{c|}{2000} & \multicolumn{1}{c|}{2005} & 2010 & 2014 & \multicolumn{1}{c|}{2018} \\
\hline Продукція сільського господарства & 40,8 & 79,7 & 79,5 & 73,3 & 64,3 & 41,2 \\
\hline Продукція рослинництва & 34,5 & 75,8 & 78,6 & 76,7 & 66,1 & 37,2 \\
\hline Зернові культури & 2,8 & 34.5 & 48,3 & 56,4 & 44,7 & 19,9 \\
\hline Цукрові буряки (фабричні) & - & 41,0 & 59,7 & 30,8 & 35,2 & 4.7 \\
\hline Картопля & 59,6 & 98,4 & 99,0 & 98,8 & 99,0 & 98,1 \\
\hline Овочі & 32,6 & 91,3 & 96,7 & 95,7 & 94,6 & 85,6 \\
\hline Плоди та ягоди & 96,1 & 97,4 & 98,9 & 94,7 & 87,1 & 78,4 \\
\hline Продукція тваринництва & 47,4 & 85,6 & 80,7 & 69,6 & 62,0 & 52,5 \\
\hline М'ясо (у забійній вазі) & 29,4 & 71,4 & 67,2 & 49,7 & 35,7 & 34,9 \\
\hline Молоко & 32,5 & 77,8 & 83,8 & 84,1 & 83,5 & 72,6 \\
\hline Яйця & 59,4 & 95,0 & 79,9 & 90,0 & 88,6 & 44,8 \\
\hline Вовна & 7,3 & 92,9 & 94,3 & 96,3 & 94,5 & 87,6 \\
\hline \multicolumn{7}{|l}{ *Джерело: статистичні дані за відповідні роки. } \\
\end{tabular}

Табличяя 5

Характеристика фермерських господарств України *

\begin{tabular}{|l|c|c|c|c|c|}
\hline \multicolumn{1}{|c|}{ Показник } & 1990 & 2000 & 2005 & 2012 & 2018 \\
\hline Кількість господарств, од. & 82 & 38428 & 42445 & 36332 & 33164 \\
\hline Загальна площа, тис. га & 2,0 & 2157,6 & 3661,2 & 4389,4 & 4707,2 \\
\hline Середня площа, га & 24,4 & 56,1 & 86,3 & 120,8 & 141,9 \\
\hline Чисельність працівників, чол.: & - & 71504 & 133534 & 100395 & 96,7 \\
\hline на одне господарство & - & 1,8 & 3,1 & 2,76 & 2,9 \\
\hline 100 га угідь & - & 3,3 & 3,6 & 2,3 & 2,1 \\
\hline
\end{tabular}

*Джерело: розроблено автором за даними Держкомстату.

32005 року по 2019 рік кількість особистих селянських господарств зменшилась на 918,8 тис. господарств, а фермерських з 2005 по 2018 рік зменшилось на 9281 господарство (Табл. 3, 4, 5). Єдиним способом вижити на селі стала самозайнятість. Вони виробляють $41,2 \%$ валової 
сільськогосподарської продукції: в тваринництві - 52,5\%, рослинництві - 37,2\% в т.ч. понад 90\% картоплі, овочів, фруктів, ягід, меду, і більше.

Організація Об'єднаних Націй оголосила 2019-2028 роки десятиліттям сімейних фермерських господарств i розробила загальний план дій, яким надає міжнародній спільноті докладні рекомендації з надання підтримки сімейним фермерським господарствам. Загальний план дій ООН, що передбачає заходи на всіх рівнях - від місцевого до глобального, сформований за 7 взаємопов'язаними напрямками роботи:

1. Розвиток сприятливого політичного середовища для зміцнення сімейних фермерських господарств.

2. Підтримка молоді й забезпечення стійкості сімейних фермерських господарств 3 покоління в покоління.

3. Сприяння досягненню гендерної рівності в сімейних фермерських господарствах.

4. Зміцнення організацій сімейних фермерських господарств.

5. Підвищення стійкості сімейних фермерських господарств до зовнішніх впливів.

6. Зміцнення сімейних фермерських господарств для забезпечення стійкості продовольчих систем до змін клімату.

7. Підтримка багатоплановості сімейних фермерських господарств для впровадження соціальних інновацій, що сприяють територіальному розвитку i збереженню довкілля та біорізноманітності.

ООН наголошує, що ведення сімейного фермерського господарства відкриває унікальну можливість для формування продовольчої безпеки, поліпшення засобів до існування, більш раціонального розпорядження природними ресурсами, охорони навколишнього середовища та досягнення сталого розвитку, особливо в сільських районах. Ініціатива покликана підкреслити роль сімейних ферм у формуванні продовольчого майбутнього планети і надати міжнародній спільноті дієві інструменти для розвитку сімейних фермерських господарств.

На жаль, в Україні протягом 2017-2019 р.р значну частку дотацій надали агрохолдингам: в т.ч. Косюку $-2568,36$ млн. грн, Бахматюку - 418,03 млн. грн, та іншим агрохолдигам приблизно 600 млн. грн.

Державна підтримка фермерських та особистих селянських господарств в Україні повинна здійснюєватися відповідно до загальнодержавних і регіональних програм за рахунок державного i місцевих бюджетів у порядку, встановленому законом. Переваги малого виробництва в сільському господарстві випливають 3 його функціонального призначення. I тут важливим $€$ те, що саме малі виробничі форми на селі забезпечують виробництво таких продуктів, які недоцільно або неможливо виробляти в умовах великого виробництва, спеціалізуються на трудомістких галузях з переважанням ручної праці.

Висновок: Враховуючи ситуацію в яку зайшли земельні відносини в Україні, кризові явища сільських територій, нераціональне використання земель сільськогосподарського призначення, спонукають до здійснення заходів державного регуляторного впливу. У Конституцію України ввести розділ «Основи аграрного та земельного устрою України», визначивши основою земельного та аграрного устрою України сільськогосподарські кооперативи, фермерські та особисті селянські господарства, як основу відновлення сільських територій. Розробити комплексну стратегію розвитку аграрного сектору де повинні мати місце принципи диференційованого застосування податкової, прямої бюджетної та регуляторної політики для кожного з типів господарювання на селі.

\section{Джерела та література}

1.Статистичний збірник. Сільське господарство України [Електронний ресурс]. Державна служба статистики України. 2018. Режим доступу : www.ukrstat.gov.ua > druk > publicat > kat_u > 2019

2. United Nations Decade of Family Farming) (A/RES/72/239, draft A/C.2/72/L.12/Rev.1) Страсбург, 27 січня 1999 року.

3. Шворак А.М. Природні кормові вгіддя та соціально-економічний розвиток сільських територій. Економічний часопис Східноєвропейського національного університету імені Лесі Украӥнки : журнал. Луцьк : Вежа-Друк, 2018. № 2 (14). С. 112 - 116. 


\section{References}

1.Statistic collection. Agriculture of Ukraine. (Electronic resource)/State statistics service of Ukraine. - 2018. Mode of admission: www.ukrstat.gov.ua > druk > publicat > kat_u > 2019

2. United Nations Decade of Family Farming) (A/RES/7̄2/239, draft A/C.2/72/L.12/Rev.1)Страсбург, 27 січня 1999 року

3.Shvorak A.M. Natural feed grounds and social-economic development of rural territories. Economic Journal of East European National University named after Lesia Ukrainka: Journal. Lutsk : Vezha-Druk, 2018. №2(14). Page 112-116.

Стаття надійшла до редакції 19.02.2020 p. 